\title{
Influence of Plum Rootstocks on the Content of Reducing Sugars in the Annual Shoots of Cultivar 'Kubanskaya Kometa'
}

\author{
Dzintra Dēķena ${ }^{1 *}$, Heljo Jänes ${ }^{2}$, Ina Alsiṇa ${ }^{3}$, Līga Lepse ${ }^{1}$ \\ ${ }^{1}$ Pūre Horticultural Research Centre, Abavas iela 2, Pūre, Tukuma nov., LV-3124, Latvia \\ ${ }^{2}$ Polli Horticultural Research Centre of the Institute of Agricultural and Environmental Sciences of the \\ Estonian University of Life Sciences, Polli 69108, Karksi-Nuia, Estonia \\ ${ }^{3}$ Latvia University of Agriculture, Liela iela 2, Jelgava, LV-3001, Latvia.
}

\begin{abstract}
The lack of suitable plum rootstocks for Baltic conditions has become a problem during recent years due to changing climatic conditions. Rapid temperature fluctuations between freezing and thawing are occurring more frequently. The winter-hardiness of rootstocks is essential for overwintering of trees in such conditions. The content of accumulated reducing sugars is an important physiological factor influencing wintering ability of trees. The dynamics of reducing sugars was investigated during two winter seasons (2010/2011 and 2011/2012) in one-year-old 'Kubanskaya Kometa' (Prunus x rossica Erem.) hybrid plum shoots from two orchards planted in 2001 at Pūre Horticultural Research Centre (Latvia) and Polli Horticultural Research Centre (Estonia). Cultivar 'Kubanskaya Kometa' was grafted on eight clonal rootstocks: 'St. Julien A', 'Brompton' cuttings, 'Ackermann', 'Pixy', GF8/1, G5/22, GF655/2, 'Hamyra' and eight seedling rootstocks: 'St. Julien INRA 2', 'St. Julien d'Orleans', 'St. Julien Noir', 'Brompton' seedlings, 'Wangenheims Zwetsche', 'St. Julien Wädenswill', 'Myrobalan' and Prunus cerasifera var. divaricata. Trees were planted at $5 \times 3 \mathrm{~m}$ spacing in four replications per rootstock with three trees per plot. Shoot samples were harvested five times during the winter period. The concentration of reducing sugars ( $\mathrm{mg} \mathrm{g}^{-1}$ dry weight) was determined with Bertran's method. Significant differences in concentration of reducing sugar were found between samples coming from different locations and in two seasons. The maximum concentration of reducing sugar was found in December or January depending on growing location and meteorological conditions.
\end{abstract}

Key words: carbohydrates, Prunus $\times$ rossica, generative rootstock, vegetative rootstock, winter-hardiness.

\section{Introduction}

Proper choice of rootstock is the key factor for successful plum production. Rootstock is the basis for the growth and development of tree. The compatibility of cultivar and rootstock also plays an important role in successful plant growth and development. The lack of appropriate rootstock in Latvia and Estonia is one of the main obstructions for establishing plum orchards. Deviations of meteorological conditions from the long term observations are registered in Latvia and Estonia during the last decades caused by global climate changes - winters become unstable with frequent thaws followed by rapid decrease of temperature. It has a very negative influence on the trees wintering (Jänes, Klaas et al., 2007, Tyurina, Demenko et al., 2000). Also, soil freezing through is not observed during last years. It confuses physiological processes in the trees. All above mentioned circumstances arouse necessity for evaluation of broadly grown and also rarely used plum rootstocks with the aim to find the most appropriate rootstock for current conditions ensuring a stable and high quality plum yield. Good winter-hardiness is mentioned as one of the main features for appropriate rootstock. Winterhardiness is determined by several factors: biological properties of rootstock and cultivar, the rate of the tree preparation for winter, compatibility of rootstock and cultivar, and others (Gryazev, 1999; Wertheim, 1998). It is necessary to find the most promising cultivar-rootstock combinations for each climate zone as well.

The myrobalan plum (Prunus cerasifera Ehrh.) has been the most broadly used rootstock in plum orchards in the region for a long period. However, this rootstock does not correspond to the demands of commercial horticulture - it produces trees of vigorous growth (Rozpara, Glowacka, 2010; Sitarek, Grzyb et al., 2007). Also, it is not suitable for hobby gardeners if gardens are located in wet soils and if there is incompatibility between rootstock and cultivar observed (Lepsis, Drudze et al. 2004).

The content of different sugars in shoots plays an important role in the wintering ability of trees. Sometimes they are referred as 'protecting substances`

\footnotetext{
* Corresponding Author's email:

dzintra.dekena@puresdis.lv
} 
during wintering period. Some authors have observed that the content of different sugars significantly increases with decreasing of the air temperature already during the autumn (Ashworth, Stirm et al. 1993). With further decrease of temperature starch gradually transforms to different sugars. It is closely related to the tree winter-hardiness. The ratio between starch and sugars changes during wintering period. Increasing of sugars content increases the cell hardiness (Morin, Ameglio et al., 2007). The changes of reducing sugar content in trees during winter period is one of the factors characterizing the compatibility between rootstock and cultivar (Genkel, Oknina, 1964) and scion winter cold resistance (Snyder and de Melo Abreu, 2005). Sugar content significantly differs also between the rootstocks per se. Also different shoots parts differs in sugar content - higher sugar content is referred for bark in comparison to wood-pulp. (Weibel et al., 2011). A. Sakai (1966) has investigated the sugar content in the trees and came to conclusion that cold resistance of hardened plants increases simultaneously with increasing of the sugar content in the cells. Carbohydrates produced in the leaves of trees are transferred to the shoots, fruits, roots and other parts, and then utilized for growth of various organs. Any excess carbohydrates are stored and used for the initial growth of shoots in spring (Yoshioka et al., 1988).

The aim of this research was to investigate the fluctuations of reducing sugars content of in oneyear- old plum shoots during wintering period.

Hypothesis - plum trees with stable content of reducing sugars during the wintering period have better winter hardiness and productivity.

Novelty - the dynamics of reducing sugars in the annual shoots of plums grafted on novel rootstocks during the wintering period is investigated in Latvia for the first time.

\section{Materials and Methods}

Investigations were done at the Pūre Horticultural Research Centre (Pūre) in Latvia and Polli Horticultural Research Centre (Polli) in Estonia. Cultivar 'Kubanskaya Kometa' (Prunus xrossica Erem.; P. salicina Lindl. $\times$ P. cerasifera Ehrh.) is a widely grown hybrid plum both in Latvia and Estonia. For this reason it was included in the investigation. It was grafted on 16 different rootstocks: eight clonal rootstocks - 'St. Julien A', 'Brompton' cuttings, 'Ackermann', 'Pixy', GF8/1, G5/22, GF655/2, 'Hamyra', and eight seedling rootstocks - 'St. Julien INRA 2', 'St. Julien d'Orleans', 'St. Julien Noir', 'Brompton' seedligs, 'Wangenheims Zwetche', 'St. Julien Wädenswill', 'Myrobalan', Prunus cerasifera var. divaricata. The experimental orchards were established in 2001 in both places. Plants were planted at $3 \times 5 \mathrm{~m}$ density, in four randomly replicates, three trees per plot. The soil was loam, with dolomite parent rock, in Pūre and sandy clay in Polli.

Reducing sugars were analysed during wintering periods of 2010/2011 and 2011/2012. One- yearold shoot samples were taken five times during the winter period: once per month in September, October, December, January and March. Five randomly chosen shoots were collected in each plot. Samples were dried in ventilated thermostat at $60{ }^{\circ} \mathrm{C}$ for 72 hours, until they reached an air-dry condition. Reducing sugars' content was analysed in the Laboratory of Plant Biochemistry of the Institute of Soil and Plant Science, Latvia University of Agriculture with Bertran's method and expressed as $\mathrm{mg} \mathrm{g}^{-1}$ dry weight (DW) (Плешков, 1976).

Meteorological data were obtained from meteorological stations in both locations.

Data obtained during two wintering seasons of 2010/2011 and 2011/ 2012 were analysed. Data were analysed using descriptive statistics and ANOVA; two factor with replication. Differences between the means were tested by the least significant difference (LSD) at 5\% significance level.

\section{Results and Discussion}

Air temperature fluctuations were found to be similar in both countries. Minimal, maximal and average air temperatures during the winter periods of 2010/2011 and 2011/2012 are summarized in Table 1.

Both wintering periods were different. In 2010, the air temperature dropped below $-15{ }^{\circ} \mathrm{C}$ already in November. In Polli, it dropped even to $-21.9{ }^{\circ} \mathrm{C}$. The winter period was relatively cold. The January of 2011 was relatively warm, when average air temperature was $4.2^{\circ} \mathrm{C}$ in Polli and $-2.4{ }^{\circ} \mathrm{C}$ in Pūre. In February 2011, the air temperature dropped down to $-33.5^{\circ} \mathrm{C}$ in Polli and $-28.5^{\circ} \mathrm{C}$ in Pūre. The autumn of 2011 was relatively warm. The air temperature rapidly decreased only in January 2012 , when it was registered $-21.7{ }^{\circ} \mathrm{C}$ in Polli, and $-22.5^{\circ} \mathrm{C}$ in Pūre and average temperature was $-5.1{ }^{\circ} \mathrm{C}$ in Polli and $-2.8{ }^{\circ} \mathrm{C}$ in Püre. The air temperature also continued to drop in February, when it reached $-10.2{ }^{\circ} \mathrm{C}$ in Polli and $-7.7^{\circ} \mathrm{C}$ in Pūre.

In Pūre significant changes of reducing sugars between the sampling times were observed during the wintering period of 2010/2011 ( $p<0.01$ ), but significant differences between rootstocks were not observed $(p=0.24)$ (Table 2$)$. The lowest content of reducing sugars was found in September for trees on all rootstocks. The lowest content of sugars was found for trees on Pixy (19.3 $\mathrm{mg} \mathrm{g}^{-1}$ ) and St. Julien INRA 2 (20.5 $\left.\mathrm{mg} \mathrm{g}^{-1}\right)$. The highest reducing sugar 
Minimal, maximal and average air temperatures

during the winter periods of 2010/2011 and 2011/2012

\begin{tabular}{llllllllc}
\hline \multirow{2}{*}{ Month } & \multirow{2}{*}{ Region } & \multicolumn{3}{c}{$2010 / 2011$} & & \multicolumn{3}{c}{$2011 / 2012$} \\
\cline { 2 - 8 } October & Polli & -4.3 & 12.9 & 4.1 & -0.8 & 15.5 & 7.3 \\
\cline { 2 - 8 } & Pure & -3.2 & 15.3 & 4.8 & -2 & 18.1 & 7.9 \\
\hline \multirow{2}{*}{ November } & Polli & -21.9 & 11.3 & 0.2 & -6.6 & 9.9 & 3.9 \\
\cline { 2 - 8 } & Pure & -15.2 & 13.3 & 2.4 & -6.2 & 11 & 5.0 \\
\hline \multirow{2}{*}{ December } & Polli & -14.4 & 0.2 & -7.9 & -3.1 & 8.5 & 1.6 \\
\cline { 2 - 8 } & Pure & -18.0 & 0.7 & -6.2 & -4.9 & 9.5 & 2.0 \\
\hline \multirow{2}{*}{ January } & Polli & -22.1 & 3.0 & 4.2 & -21.7 & 4.2 & -5.1 \\
\cline { 2 - 8 } & Pure & -16.9 & 3.7 & -2.4 & -22.5 & 6.4 & -2.8 \\
\hline \multirow{2}{*}{ February } & Polli & -33.5 & 2.3 & -11.0 & -32.1 & 3.1 & -10.2 \\
\cline { 2 - 8 } & Pure & -28.5 & 4.5 & -8.9 & -29.7 & 8.2 & -7.7 \\
\hline \multirow{2}{*}{ March } & Polli & -15.3 & 8.7 & -1.1 & -19.0 & 9.9 & -0.1 \\
\cline { 2 - 8 } & Pure & -16.9 & 8.7 & 0.1 & -13.0 & 15 & 1.8 \\
\hline
\end{tabular}

content was observed for trees grafted on St. Julien Noir (39. $8 \mathrm{mg} \mathrm{g}^{-1}$ ) and St. Julien A. (31. $2 \mathrm{mg} \mathrm{g}^{-1}$ ).

In October, the content of reducing sugars significantly increased. The highest contents were observed for trees on 'GF 8/1' (52.7 $\left.\mathrm{mg} \mathrm{g}^{-1}\right)$ and 'St. Julien A' (50.1 $\left.\mathrm{mg} \mathrm{g}^{-1}\right)$. During December and January the content of reducing sugars differed between rootstocks and it was 30.0 to $37.6 \mathrm{mg} \mathrm{g}^{-1}$. It indicates the different influence of rootstock on the tree wintering ability in negative air temperature. It is mentioned by several authors that the best over wintering ability is observed for trees where the content of different sugars increases with decreasing of air temperature (Genkel, Oknina, 1964). In our case such tendency was more marked for GF 5/22 and St. Julien Noir rootstocks in this wintering season.

Also, during 2011/2012 the lowest content of reducing sugars was observed in September. Cultivar 'Kubanskaya Kometa' has an early ripening time and its tree matures late; in addition, the dormancy period for this cultivar is short. This influences physiological processes in the plant in critical periods. The content of reducing sugars slightly increased during October (Table 2).

During this wintering period in Pūre the highest content of reducing sugars for trees on all rootstocks was fixed in December and January. It allows to assume that trees were well prepared for the wintering period. The reason of such good condition of trees can be the warm autumn - in November the minimal temperature in Pūre was registered $6.5^{\circ} \mathrm{C}$. It is favourable for tree hardening and preparation for the wintering period. At about $-5^{\circ} \mathrm{C}$ the biochemical processes take place and starch transforms to sugars (Krasavtsev, 1973; Krasavtsev 1967). The lowest content of reducing sugars during this wintering period was observed in September for trees on rootstocks 'Ackermann' (10.6 mg g-1), 'Brompton' cuttings (18.3 $\mathrm{mg} \mathrm{g}^{-1}$ ) and 'St. Julien d' Orleans' $\left(18.3 \mathrm{mg} \mathrm{g}^{-1}\right)$. The highest changes of reducing sugar level were found for trees grafted on 'Brompton' seedlings (21.5 mg g ${ }^{-1}$ in September and $49.2 \mathrm{mg} \mathrm{g}^{-1}$ in January) and on 'Ackermann' (10.6 $\mathrm{mg} \mathrm{g}^{-1}$ in September and $42.0 \mathrm{mg} \mathrm{g}^{-1}$ in January). The lowest changes were observed for trees on 'GF 655/2' (25.0 $\mathrm{mg} \mathrm{g}^{-1}$ in September and 44.6 in January), on 'Pixy' (26.7 and $45.8 \mathrm{mg} \mathrm{g}^{-1}$, respectively) and on 'St. Julien Wädenswill' (23.2 and $42.7 \mathrm{mg} \mathrm{g}^{-1}$, respectively). All these rootstocks belong to the group of Prunus domestica and Prunus insititia (P.domestica ssp. insititia) with long dormancy period and therefore with a genetically determined good wintering ability.

The sum of minimal temperatures in Polli, Estonia, is higher if compared with Pūre, Latvia, but possibility of thaws is less. In the wintering period of 2010/2011 in Polli the content of reducing sugars in the trees on different rootstocks was fluctuating. 
The dynamics of reducing sugars in one-year-old shoots

Table 2 in the wintering period of 2010/2011 and 2011/2012 in Pūre

\begin{tabular}{|c|c|c|c|c|c|c|c|c|c|c|}
\hline \multirow[b]{2}{*}{ Rootstocks } & \multicolumn{2}{|c|}{ September } & \multicolumn{2}{|c|}{ October } & \multicolumn{2}{|c|}{ December } & \multicolumn{2}{|c|}{ January } & \multicolumn{2}{|c|}{ March } \\
\hline & $\begin{array}{c}2010 / \\
2011\end{array}$ & $\begin{array}{l}2011 / \\
2012\end{array}$ & $\begin{array}{c}2010 / \\
2011\end{array}$ & $\begin{array}{l}2011 / \\
2012\end{array}$ & $\begin{array}{c}2010 / \\
2011\end{array}$ & $\begin{array}{l}2011 / \\
2012\end{array}$ & $\begin{array}{c}2010 / \\
2011\end{array}$ & $\begin{array}{c}2011 / \\
2012\end{array}$ & $\begin{array}{c}2010 / \\
2011\end{array}$ & $\begin{array}{l}2011 / \\
2012\end{array}$ \\
\hline Ackermann & 23.1 & 10.7 & 36.0 & 30.2 & 41.1 & 42.0 & 35.1 & 40.0 & 41.0 & 31.4 \\
\hline St. Julien INRA2 & 20.5 & 19.7 & 40.2 & 41.9 & 30.3 & 45.0 & 39.6 & 37.2 & 33.3 & 26.1 \\
\hline Brompton seedlings & 24.5 & 21.6 & 46.0 & 28.6 & 43.3 & 44.5 & 35.0 & 49.3 & 44.9 & 33.0 \\
\hline Myrobalan & 29.8 & 21.2 & 50.4 & 35.4 & 45.1 & 44.5 & 35.1 & 40.8 & 38.2 & 31.7 \\
\hline GF $8 / 1$ & 24.2 & 24.6 & 52.7 & 32.7 & 44.6 & 44.8 & 32.0 & 46.8 & 45.9 & 32.5 \\
\hline G 5/22 & 27.4 & 20.6 & 36.0 & 29.8 & 44.3 & 42.5 & 38.4 & 43.3 & 35.3 & 32.8 \\
\hline St.Julien d’ Orleans & 22.2 & 18.3 & 42.2 & 30.5 & 41.1 & 42.4 & 35.0 & 39.0 & 41.8 & 32.1 \\
\hline Brompton cuttings & 25.5 & 18.7 & 42.4 & 30.1 & 41.3 & 40.7 & 30.0 & 43.5 & 37.4 & 29.5 \\
\hline St.Julien Noir & 39.8 & 25.2 & 39.8 & 35.8 & 44.3 & 44.3 & 38.4 & 40.4 & 43.0 & 27.5 \\
\hline St.Julien Wädenswill & 27.5 & 23.3 & 37.3 & 33.3 & 41.8 & 42.8 & 35.4 & 40.8 & 37.7 & 26.9 \\
\hline Wangenheims Zwetsche & 27.1 & 24.5 & 47.0 & 32.1 & 38.7 & 44.0 & 33.3 & 43.9 & 35.9 & 29.0 \\
\hline St Julien A & 31.2 & 24.7 & 50.1 & 30.9 & 39.1 & 41.4 & 32.8 & 45.8 & 39.5 & 36.7 \\
\hline Pixy & 19.3 & 26.8 & 51.1 & 31.9 & 47.6 & 45.4 & 36.0 & 39.6 & 42.8 & 31.8 \\
\hline Hamyra & 25.1 & 24.2 & 43.2 & 33.8 & 39.0 & 45.8 & 35.3 & 46.3 & 41.8 & 28.4 \\
\hline P. cerasifera & 23.0 & 23.0 & 47.6 & 34.5 & 31.2 & 42.4 & 34.7 & 35.2 & 43.6 & 21.8 \\
\hline GF $655 / 2$ & 21.7 & 25.0 & 47.8 & 32.5 & 41.7 & 44.6 & 35.7 & 37.6 & 45.7 & 33.1 \\
\hline $\mathrm{LSD}_{0.05}$ & 5.43 & 4.16 & 5.43 & 4.16 & 5.43 & 4.16 & 5.43 & 4.16 & 5.43 & 4.16 \\
\hline
\end{tabular}

The highest content of reducing sugars for trees on all rootstocks was observed in October (Table 3). It is not clear what caused so rapid increase of reducing sugars in October, because no sharp temperature decrease was observed in September and October. Fluctuations of sugar content in the middle of the winter - in December and January were not observed, but it decreased in March. It leads to assumption that trees of cultivar 'Kubanskaya Kometa' entered the period of dormancy earlier and earlier started the vegetation. The highest content of reducing sugars in October was stated for trees grafted on 'GF 8/1' (54.1 $\left.\mathrm{mg} \mathrm{g}^{-1}\right)$, which is an inter-species hybrid (Prunus cerasifera $\times$ Prunus munsoniana), and on 'Pixy' (55.9 $\left.\mathrm{mg} \mathrm{g}^{-1}\right)$. The lowest sugar content was stated for trees on 'Myrobalan' (Prunus cerasifera. var. myrobolana ) (40.1 $\left.\mathrm{mg} \mathrm{g}^{-1}\right)$. These trees finished vegetation later. The sharpest change of sugar content within the whole wintering period were observed for trees grafted on 'GF 655/2' (52.5 $\mathrm{mg} \mathrm{g}^{-1}$ in
October and $18.4 \mathrm{mg} \mathrm{g}^{-1}$ in March) and on 'Pixy' (55.9 and $21.9 \mathrm{mg} \mathrm{g}^{-1}$ respectively). The less change was observed for trees on 'Myrobalan' (40.2 and $22.1 \mathrm{mg} \mathrm{g}^{-1}$ respectively).

During the wintering period of 2011/2012 significant differences $(\mathrm{p}<0.01)$ concerning the content of reducing sugars in shoots between months were found also in Polli while significant differences between rootstocks were not stated $(p=0.52)$. The lowest content of reducing sugars for all rootstocks was in September. Similar to results obtained in Pūre during the wintering season of 2010/2011, the lowest content of reducing sugars was observed for trees on rootstock 'Pixy' (16.7 $\left.\mathrm{mg} \mathrm{g}^{-1}\right)$. The highest content of reducing sugars was found for trees on rootstock 'St. Julien Noir' (32.4 $\mathrm{mg} \mathrm{g}^{-1}$ ) (Table 3). In October the content of reducing sugars increased for all rootstocks. It continued to increase also in December and January and even in March. It differs from previously described results, when the highest 
The dynamics of reducing sugars in one-year-old shoots

Table 3

\section{in the wintering period of 2010/2011 and 2011/2012 in Polli}

\begin{tabular}{|c|c|c|c|c|c|c|c|c|c|c|}
\hline \multirow[b]{2}{*}{ Rootstocks } & \multicolumn{2}{|c|}{ September } & \multicolumn{2}{|c|}{ October } & \multicolumn{2}{|c|}{ December } & \multicolumn{2}{|c|}{ January } & \multicolumn{2}{|c|}{ March } \\
\hline & $\begin{array}{c}2010 / \\
2011\end{array}$ & $\begin{array}{c}2011 / \\
2012\end{array}$ & $\begin{array}{c}2010 / \\
2011\end{array}$ & $\begin{array}{c}2011 / \\
2012\end{array}$ & $\begin{array}{c}2010 / \\
2011\end{array}$ & $\begin{array}{l}2011 / \\
2012\end{array}$ & $\begin{array}{c}2010 / \\
2011\end{array}$ & $\begin{array}{l}2011 / \\
2012\end{array}$ & $\begin{array}{c}2010 / \\
2011\end{array}$ & $\begin{array}{l}2011 / \\
2012\end{array}$ \\
\hline Ackermann & 28.6 & 24.3 & 41.6 & 35.7 & 39.7 & 52.8 & 37.2 & 47.4 & 21.9 & 51.1 \\
\hline St. Julien INRA2 & 26.9 & 25.3 & 51.5 & 42.0 & 32.8 & 44.1 & 44.0 & 44.2 & 26.1 & 58.6 \\
\hline Brompton seedlings & 28.6 & 22.7 & 46.2 & 41.7 & 38.9 & 49.9 & 29.0 & 46.3 & 19.7 & 46.1 \\
\hline Myrobalan & 25.0 & 30.3 & 40.2 & 39.4 & 34.6 & 49.2 & 29.9 & 44.9 & 22.1 & 50.4 \\
\hline GF 8/1 & 29.7 & 28.4 & 54.2 & 53.2 & 40.1 & 50.3 & 37.6 & 44.8 & 23.6 & 57.7 \\
\hline G 5/22 & 26.0 & 27.9 & 42.8 & 45.5 & 34.6 & 45.1 & 33.3 & 42.6 & 23.3 & 56.3 \\
\hline St.Julien d' Orleans & 31.1 & 25.3 & 41.2 & 32.3 & 36.2 & 52.3 & 39.4 & 42.2 & 21.8 & 56.5 \\
\hline Brompton cuttings & 31.4 & 26.4 & 46.3 & 44.1 & 33.6 & 48.4 & 41.0 & 45.3 & 24.6 & 52.0 \\
\hline St.Julien Noir & 26.1 & 32.4 & 48.5 & 40.8 & 41.9 & 42.9 & 28.6 & 49.4 & 22.9 & 48.8 \\
\hline St.Julien Wädenswill & 27.2 & 29.1 & 52.0 & 43.0 & 37.8 & 42.5 & 34.8 & 44.5 & 21.7 & 44.7 \\
\hline Wangenheims Zwetsche & 36.6 & 29.6 & 52.1 & 41.1 & 35.3 & 43.5 & 37.1 & 41.5 & 21.1 & 45.3 \\
\hline St Julien A & 30.3 & 31.3 & 44.3 & 45.3 & 40.6 & 43.4 & 26.9 & 47.9 & 23.1 & 53.4 \\
\hline Pixy & 29.6 & 16.7 & 55.9 & 39.3 & 34.8 & 31.0 & 34.0 & 47.9 & 21.9 & 56.5 \\
\hline Hamyra & 29.7 & 26.4 & 48.0 & 46.0 & 31.0 & 42.8 & 37.3 & 49.7 & 18.7 & 60.8 \\
\hline P. cerasifera & 37.7 & 30.7 & 49.3 & 43.1 & 35.1 & 43.8 & 37.0 & 49.4 & 18.9 & 44.7 \\
\hline GF $655 / 2$ & 24.7 & 29.0 & 52.5 & 45.9 & 30.1 & 50.5 & 32.7 & 43.8 & 18.5 & 49.4 \\
\hline $\mathrm{LSD}_{0.05}$ & 4.87 & 6.59 & 4.87 & 6.59 & 4.87 & 6.59 & 4.87 & 6.59 & 4.87 & 6.59 \\
\hline
\end{tabular}

content of reduced sugars was observed only in December and January. It can be explained by stable negative temperatures and snow cover in this region. The sharpest changes of sugar content in this wintering period were observed for trees grafted on 'Pixy' (16.7 $\mathrm{mg} \mathrm{g}^{-1}$ in September and $56.5 \mathrm{mg} \mathrm{g}^{-1}$ in March). According to data from literature, the activity of starch is decreasing by half and the amount of different sugars is increasing during wintering period because the starch is transforming to sugars. These sugars play important role in reducing of cold and frost damages (Yoshioka, Nagai et al., 1988). It is mentioned also in other investigations where close positive correlation between frost resistance and sugar content fluctuations was found (Sakai, 1962). Frost resistance increases with the increase of sugar content in cells for hardened plants (Sakai, 1966).

The common tendency is observed for both regions, both wintering periods and all rootstocks in September and October. The lowest content of reducing sugars was observed in September, and it increased till October (Fig. 1).

It corresponds to the results referred by other authors. A. Sakai found that sugar content in trees increases in the period from October till January (Sakai, 1962), or even till February (Gaudillere, Mang et al., 1992). In our study the highest content of reducing sugars in December and January was observed in the season of 2011/2012 in Polli. It had a tendency to increase also during March. A similar tendency was also observed in Pūre, in both wintering periods. It can be caused by critical temperatures in February during both wintering periods. In Polli, in March 2011 the content of reducing sugars sharply decreased. It can be explained by activation of vital processes in this spring. Other researches show that there can be significant difference between various rootstock and cultivar combinations in the content of different sugars and starch (Gaudillere, Mang et al.,1992). It was also observed in our investigation. 


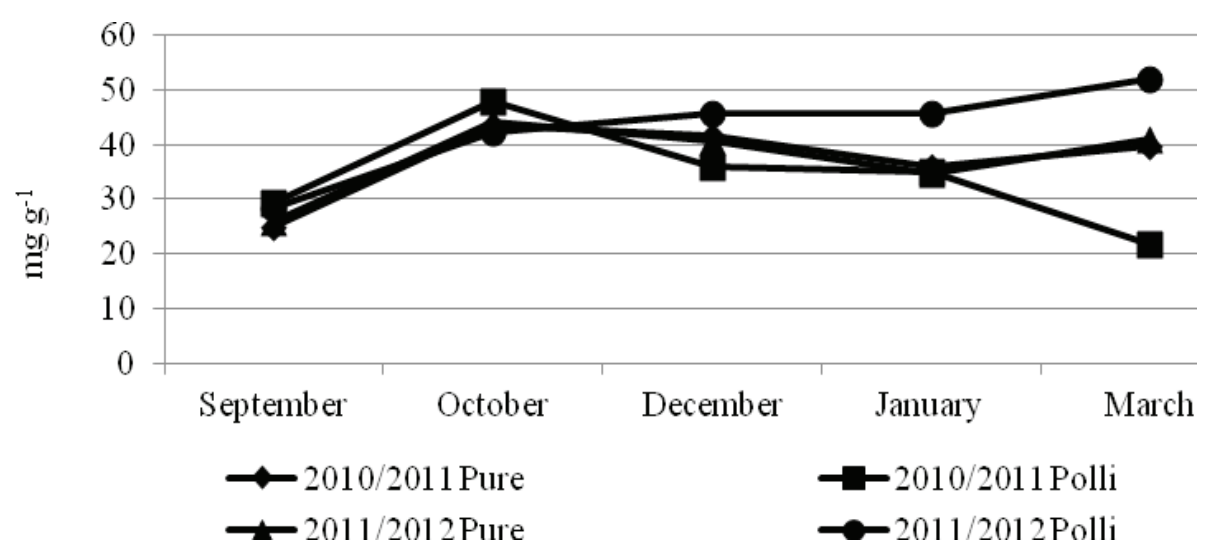

Fig. 1. The average content of reducing sugars in one-year-old shoots in the wintering period of 2010/2011 and $2011 / 2012\left(\operatorname{LSD}_{0.05}=3.89\right)$.

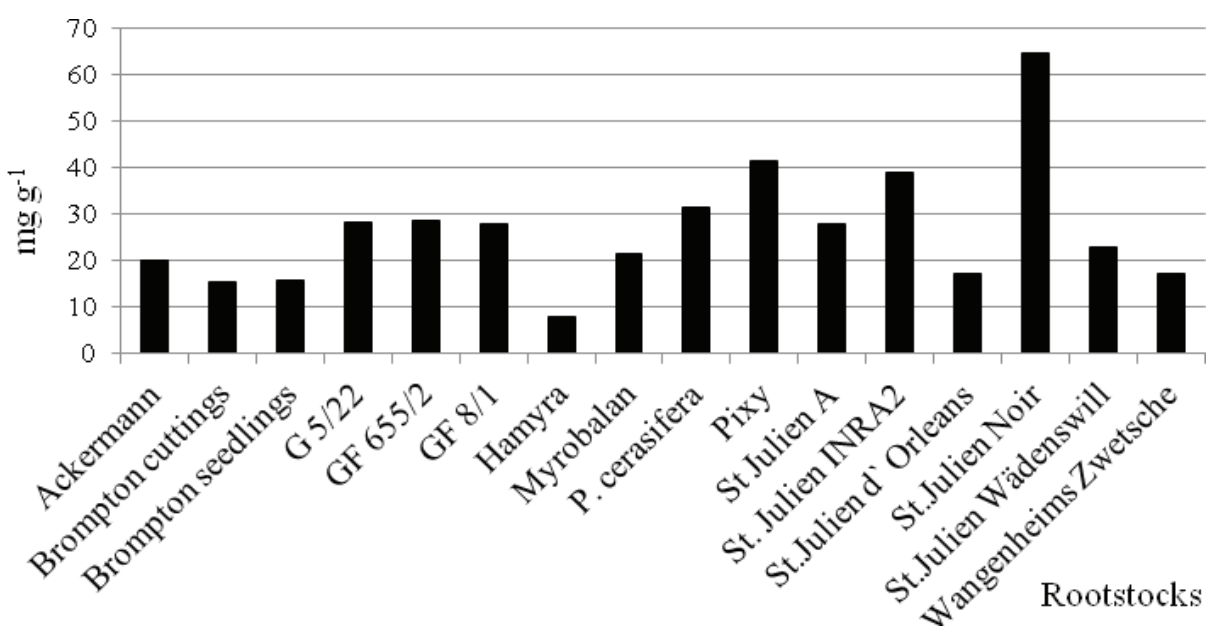

Fig.2. Deviation of the average reducing sugar content in the wintering period of 2010/2011 in Pūre.

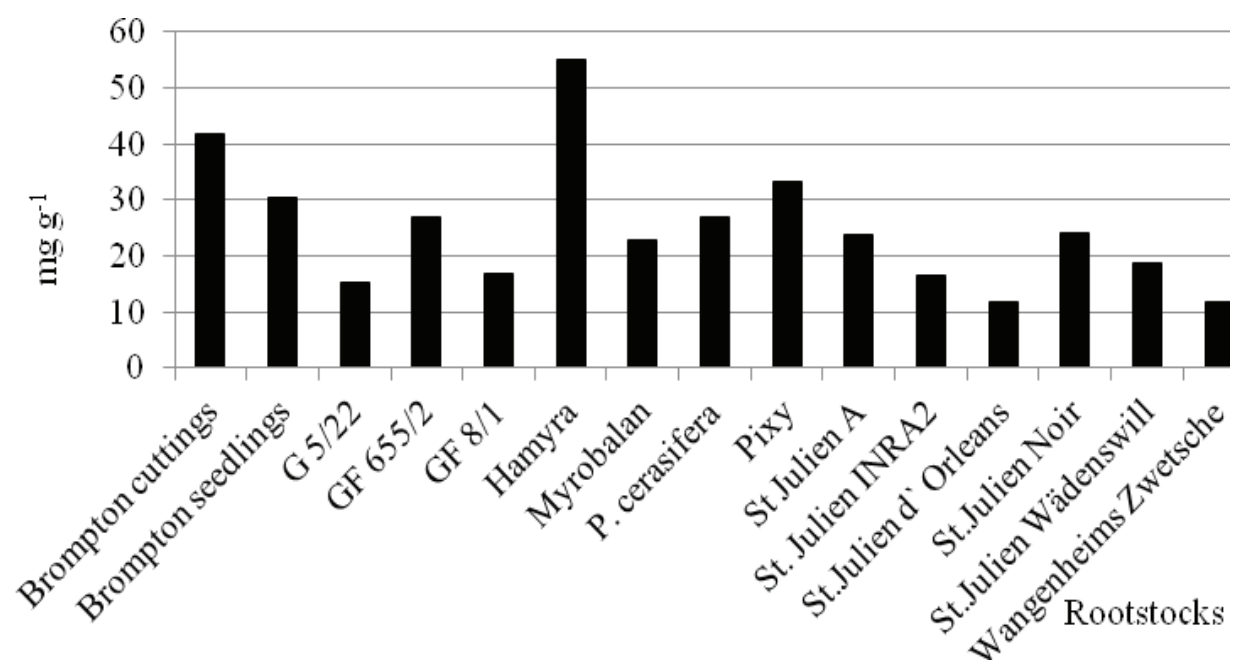

Fig.3. Deviation of the average reducing sugar content in the wintering period of 2011/2012 in Pūre. 

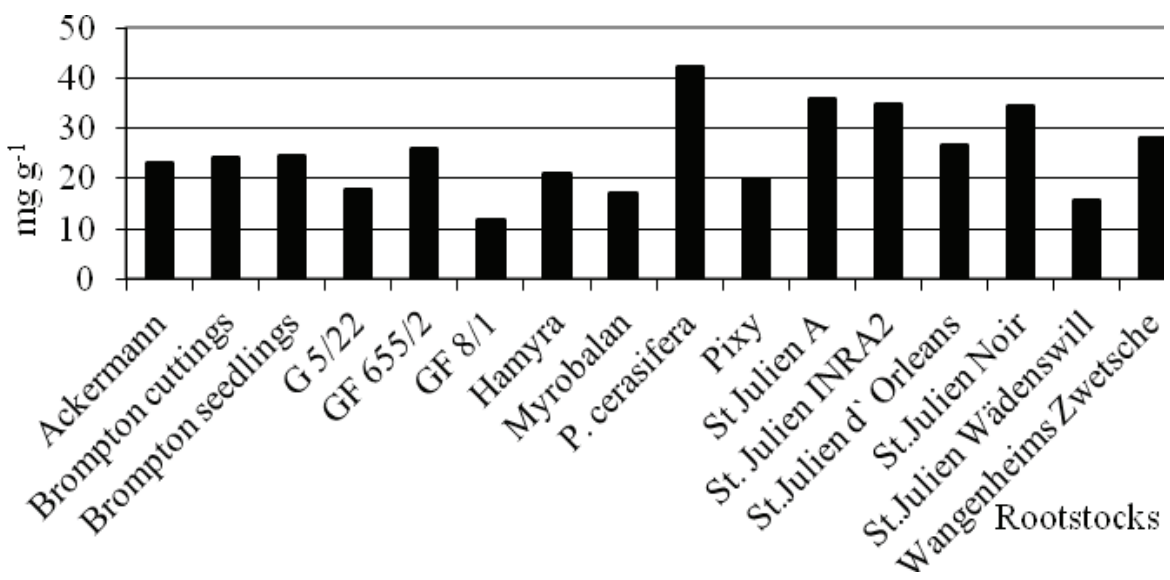

Fig.4. Deviation of the average reducing sugar content in the wintering period of 2010/2011 in Polli.

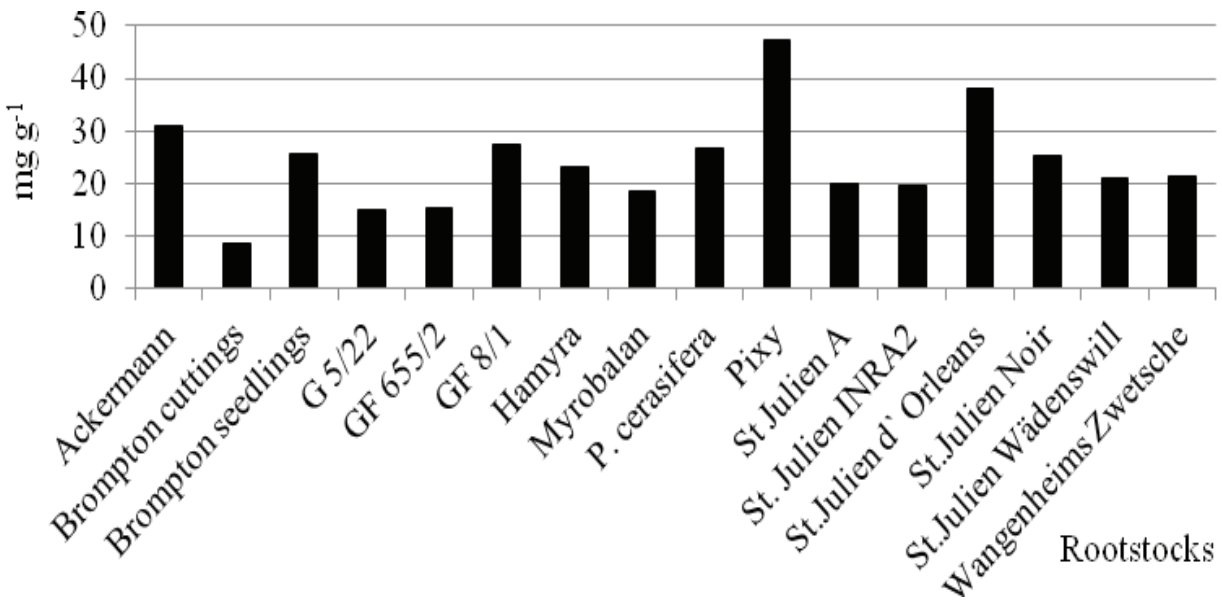

Fig.5. Deviation of the average reducing sugar content in the wintering period of 2011/2012 in Polli.

There were various fluctuations within seasons between rootstocks. The evaluation of the sugar content deviation from the average showed that results differ between rootstocks within years and growing regions. Take for example rootstock 'Hamyra' that had the lowest sugar content deviation from the average in the wintering season 2010/2011 at Pūre (Fig. 2), but it had the highest deviation in the wintering season of 2011/2012 (Fig. 3).

It indicates that different rootstocks in different meteorological conditions react differently. In Polli, during wintering period of 2010/2011 the lowest deviations from the average were found for trees on rootstock 'GF8/1' (Fig. 4). In 2011/2012 the lowest deviations from the average were stated for 'Brompton' cuttings (Fig.5).

Therefore, after only two years of investigations it is not possible to select the most appropriate rootstocks for every growing region. Only the main tendency can be discussed. In comparison of two growing regions, it was observed that higher fluctuations of reduced sugar content occurred in Polli compared to Pūre.

\section{Conclusions}

1. The content of reducing sugars for cultivar 'Kubanskaya Kometa' differed between rootstocks used, wintering seasons and growing regions.

2. Higher fluctuations within the content of reducing sugars were observed in Polli compared to Pūre. Significant differences between months were found.

3. In Pūre in average of two testing years, the highest content of reducing sugars was observed for plums grafted on 'Wangenhems Zwetsche' (39.0 $\mathrm{mg} \mathrm{g}^{-1)}$, 'St. Julien Noir' (38.71 $\mathrm{mg} \mathrm{g}^{-1}$ ) and 'St. Julien d' Orleans' (37.83 $\left.\mathrm{mg} \mathrm{g}^{-1}\right)$. In Polli, the highest content of reducing sugars was 
observed for plums grafted on $P$. cerasifera var. divaricata (42.0 $\left.\mathrm{mg} \mathrm{g}^{-1}\right)$, GF 8/1 (39.6 $\mathrm{mg} \mathrm{g}^{-1}$ ) and 'St. Julien Noir' (39.3 $\left.\mathrm{mg} \mathrm{g}^{-1}\right)$.

4. In both wintering periods the highest sugar content deviations from the average were observed in trees grafted on 'St Julien Noir', 'Hamyra', 'Pixy' and Prunus cerasifera var. divaricata.

5. In the wintering period of 2010/2011 the highest content of reducing sugars was found in October in both growing regions. In the wintering period of 2011/2012, in Polli the highest content of reducing sugars was found in March, but in Pūre it was in January.

\section{References}

1. Ashworth, E.N., Stirm, V.E. \& Volenec, J.J. (1993). Seasonal variations in soluble sugars and starch within woody stems of Cornus sericea L. Tree Physiology, 13, $379-388$.

2. Braun, J. W., Helton, A. W. \& Duane LeTourneau (1971). Soluble Carbohydrates in the bark of Italian prune (Prunus domestica) trees. Plant Physiology, 24, $214-217$.

3. Gaudillere, J. P., Mang, A. \& Carbone, F. (1992). Vigour and non-structural carbohydrates in young prune trees. Scientia Horticulturae, 51, $197-211$.

4. Genkel, P.A., Oknina, E.Z. (1964). Состояние покоя и морозоустойчивость плодовых paстений. (Dormancy and frost hardiness of fruit plants). Москва: Наука. 241. (in Russian).

5. Gryazev, V. (1999). Выращивание саженцев для высокопродуктивных садов (Growing of plants for highly productive orchards). Stavropol, Kavkazskiy kray. (in Russian).

6. Jänes, H., Klaas, L. \& Pae, A. (2007). Winter hardiness of plum on different rootstocks in winter 2002/2003 in Estonia. Acta Horticulturae, 734, 295-298.

7. Krasavtsev, O. A. (1967). Frost hardening of woody plants at temperature below zero. Injury and resistance in freezing organisms. Hokkaido, 131. - 141.

8. Krasavtsev, О. А. (1973). Значение начальных отрицательных температур для закаливания растений к морозу (The importance of initial temperatures below zero in plant frost hardening). Plant Physiology. 20 (1), 24 - 31. (in Russian).

9. Lepsis, J., Drudze, I. \& Dekens, U. (2004). The evaluation of different plum and pear rootstocks in the nursery. Acta Horticulturae, 658(1), 167 -171 .

10. Morin, X., Ameglio, T. \& Ahas, R. (2007). Variation in cold hardiness and carbohydrate concentration from dormancy induction to bud burst provenances of three European oak species. Tree physiology, 27, 817 - 825.

11. Pleshkov, B. P. (1976). Практикум по биохимии растений (Practical guide of plant biochemistry). Moscow. Kolos. (in Russian).

12. Rozpara, E., Glowacka, A. \& Grzyb, Z. S. (2010). The growth and yields of eight plum cultivars grafted on two rootstocks in central Poland. Acta Horticulturae, 874, 255 - 259.

13. Sakai, A. (1962). Studies on the frost hardiness on woody plants. I. The causal relation between sugar content and frost- hardiness. Bulletin of HUSCAP, Hokkaido, 40 p.

14. Sakai, A. (1966). Studies of frost hardiness in woody plants. II. Effect of temperature on hardening. Plant physiology, 41, 353-359.

15. Sitarek, M., Grzyb, Z. \& Kozinski, B. (2007). Effect of four different rootstocks on the growth, yield and fruit quality of 'Valor' plum trees. Acta Horticulturae, 734(1), 413 - 416.

16. Snyder,R.L. \& De Melo-Abreu, J.P. (2005). Frost protection: Fundamentals, Practice and Economics. Vol.1. United Nations, FAO, Rome, 126.

17. Tyurina, M. M., Demenko, V. I., Goloulina, L. K., Eczedi J. J. \& Arsentyev, A. P. (2000). Физиология зимостойкости, роста и плодоношения у плодовых и ягодных растений (Physiology of winter toleration, growth and fructification by fruit and small fruit plants). Scientific works of the International Conference "The history, present time and the perspective progress of the Russian horticulture", 15 - 17 November, 2000, Moscow, 192-220. (in Russian).

18. Weibel, A. M., Dejong, T. M., Reighard, G. I. \& Rajapakse, N. C. (2011). Dormant carbohydrate reserves of two peach cultivars grafted on different vigor rootstocks. Acta Horticulturae, 903(2), $815-820$.

19. Wertheim, S.J. (1998). In: Rootstock Guide. European plum), Netherlands, Fruit research station Wilhelminadorp, 115 - 137.

20. Yoshioka, H., Nagai, K., Aoba, K. \& Fukumoto, M. (1988). Seasonal changes of carbohydrates metabolism in apple trees. Scientia Horticulturae, $36,219-227$. 